\title{
PENERTIBAN ADMINISTRASI DESA MENUJU PENINGKATAN PELAYANAN PUBLIK
}

\author{
Langgeng Rachmatullah Putra, Abi Ibnu Majid, Ganis Anjar Cahyani, Rensi Novia \\ Ekasari, Yunita Aldama, Hanifatul Hikmah, Eka Prameswari Devi, Octivari Rosania A., \\ Miftakhul Aini, Yoke Pradila Agatha, Redra Indah Hana Gunawan \\ Fakultas Ilmu Administrasi, Universitas Islam Malang
}

Korespondensi email: langgengputra@unisma.ac.id

\begin{abstract}
ABSTRAK
Penertiban administrasi merupakan hal terpenting dalam tatanan pemerintahan karena dari penertiban adminsitrasi pemerintahan bisa memberikan pelayanan pablik yang prima terhadap masyarakat, oleh karena itu urusan pemerintahan oleh pemerintah desa dan badan permusyawaratan desa dalam mengatur dan mengurus kepentingan masyarakat, Pemerintahan desa harus melaksanakan dengan baik sehingga mampu mendukung pelaksanaan fungsi administrasi pemerintah desa. Disamping itu pemerintah desa dan kelurahan merupakan satu aspek yang di anggap penting dalam rangka peningkatan dan pengembangan kinerja aparatur pemerintah desa serta pelaksanaan pemerintahan desa sehingga berdampak terhadap pelayana terhadap masyarakat, baik pelayanan kesehatana, administrasi kependudan dan lain-lain. Metode yang di gunakan adalah dengan metode wawancara, yaitu mendapat informasi atau data dengan cara bertanya langsung kepada responden. Hasil penelitian menunjukkan adanya proses-proses administratif yang telah dijalankan namun masih perlu beberapa perbaikan.
\end{abstract}

Kata Kunci: administrasi; pelayanan publik; kinerja aparatur pemerintahan.

\section{PENDAHULUAN}

Penertiban administrasi merupakan cara suatu lembaga mengarsipkan atau menertibkan suatu administrasi lembaganya dengan baik, penertiban administrasi suatu lembaga sangat penting karena penertiban administrasi secara sederhana adalah bentuk kegiatan dalam hal yang meliputi pencatatan, surat-menyurat serta pembukuan dalam hal ketatausahaan (Pratama, 2020). Pemerintahan Desa adalah penyelengaraan urusan pemerintahan oleh pemerintah desa dan badan permusyawaratan desa dalam mengatur dan mengurus kepentingan masyarakat setempat berdasarkan asal usul dan adat istiadat setempat yang diakui dan dihormati dalam sistem pemerintahan Negara Kesatuan Republlik Indonesia (Suharto, 2012).

Selanjutnya dalam melaksanakan tugas, fungsi dan wewenang pemerintahan desa tidak lepas dari peran pelaksanaan administrasi pemerintahan desa itu sendiri, yang dilaksanakan untuk mengelola segenap kegiatan pemerintahan, pembangunan dan kemasyarakatan desa (Arsjad, 2018). Penertiban administrasi merupakan cara mengarsipkan atau menertibkan suatu administrasi lembaganya dengan baik, penertiban administrasi suatu lembaga sangat penting karena penertiban administrasi secara 
sederhana adalah bentuk kegiatan dalam hal yang meliputi pencatatan, surat-menyurat serta pembukuan dalam hal ketatausahaan (Hidayat, 2018).

Pemerintahan desa harus dilaksanakan dengan baik sehingga mampu mendukung pelaksanaan fungsi administrasi pemerintahan di desa. Disamping itu pemerintahan desa dan kelurahan merupakan salah satu aspek yang dianggap penting dalam rangka peningkatan dan pengembangan kinerja apartur pemerintahan desa serta pelaksanaan pembangunan di desa. Hal ini karenapenertiban administrasi di desa merupakan ujung tomba dalam melaksanakan pembangunan desa beserta aspek-aspek tugas pemerintahan, pembangunan dan kemasyarakatan yang dibebankan kepadanya (Saleh, 2008). Peningkatan dan pengembangan administrasi pemerintahan desa diharapkan dapat berperan untuk melaksanakan tugas-tugas administrasi yang di bebankan kepada pemerintahan desa. Dalam struktur pemerintahan desa terdapat seperangkat aparat yang memiliki tugas untuk melaksanakan pengelolaan administrasi sebagai komponen penyelengaraan tugas-tugas pemerintahan desa (Pujiatna et al., 2019).

Pemerintahan desa harus melaksanakan dengan baik sehingga mampu mendukung pelaksanaan fungsi administrasi pemerintah desa. Disamping itu pemerintah desa dan kelurahan merupakan satu aspek yang di anggap penting dalam rangka peningkatan dan pengembangan kinerja aparatur pemerintah desa serta pelaksanaan pemerintahan desa (Paramitha et al., 2013). Hal ini karena penertiban administrasi di desa merupakan tombak melaksanakan pembangunan desa beserta aspek aspek tugas pememrintahan, pembangunan kemasyarakatan yang di bebankan kepadaya. Pelayanan di Desa Sidomulyo haruslah berkualitas, maka para pegawai harus benar-benar SDM yang memiliki kemampuan tinggi dalam memberikan pelayanan. Dengan begitu masyarakat akan mendapatkan kepuasan yang menjadi harapan. Mereka tahu apa yang menjadi kebutuhan masyarakat, maka tahu apa yang harus dilakukan sesuai dengan standart pelayanan yang berkualitas. Kemampuan merupakan salah satu unsur dalam kematangan, berkaitan dengan pengetahuan atau keterampilan yang dapat diperoleh dari pendidikan, latihan dan suatu pengalaman. Adapun kemampuan unsur yang lain dari kematangan bertalian dengan keyakinan diri dan motivasi seseorang.

\section{METODE}

Metode yang di gunakan adalah dengan metode wawancara, yaitu mendapat informasi atau data dengan cara bertanya langsung kepada responden dalam hal ini data di poroleh dengan melakukan wawancara dengan sekretaris desa dan kepala desa. Lokasi dilakuakan di desa Sidomulyo, kecamatan batu kota batu, dengan waktu yang di gunakan untuk program ini dimulai dari bulan Agustus sampai sampai September 2020. Ada beberapa persoalan administrasi harus di selesaikan sehingga pemerintahan desa harus melakukan sosialisasi tentang pentingnya administrasi kepandudukan, seperti KK, Akta kelahira, akta kematian, KTP, ada beberapa masyarakat menggap hal sepele sehinnga tidak mengurusnya.

\section{HASIL DAN PEMBAHASAN}

Administrasi publik sebenarnya sudah ada semenjak dahulu kala. Ia akan timbul dalam suatu masyarakat yang terorganisasi. Dalam catatan sejarah peradaban manusia, maka di Asia Selatan termasuk di Indonesia Cina dan Mesir Kuno dahulu sudah didapatkan suatu sistem penataan pemerintah. Sistem penataan tersebut pada saat sekarang dikenal dengan sebutan administrasi publik/Negara. Administrasi dalam arti luas adalah segenap proses kegiatan umtuk mencapai tujuan, sedangkan daministrasi dalam arti yang sempit adalah segenap proses pelayanan yang dilakukan untuk mencapai tujuan yang telah 
ditentukan sebelumnya. Proses pelayanan ini dapat diartikan sebagai penyelengaraan ataupun proses kegiatan (Nasikhah, 2019).

Administarsi mempunyai dua arti yaitu administrasi dalam arti luas dan administrasi dalam arti sempit. Secara sempit administarsi diajukan sebagai kegiatan tulis menulis tentang segala sesuatu yang terjadi dalam organisassi atau usaha. jadi administrasi tak lebih dari perkerjaan tata usaha. seperti perkerjaan mengetik.dan lainnya (proses pelayanan) sedangkan dalam arti luas merupakan kgiatan yang dilakukan untuk mencapai tujuan. Kegiatan ini meliputi kegiatan perencanaan, pengorganisasian, pengerakan dan pengawasan. Administrasi diartikan sebagai suatu proses penorganisasian sumber-sumber sehingga tugas perkerjaan dalam organisasi tinggkat apapun dapat dilaksanakan dengan baik. proses administrasi akan melaksanakan tiga fingsi utama yang berhubungan erat dengan tiga tingkatan umum dalam hiarki formal di tingkat atas yaitu fungsi pengarahan organisasi terutama berkaitan dengan proses perencanaan jangka panjang dari suatu tujuan yang akan dicapai.ditingkat menengah yaitu fungsi manajemen organisasi terutama berkaitan dengan upaya mempertahankan organisasi sebagai suatu perkerjaan yang terus berlangsung lama, seperti memberikan bahan-bahan, sarana-sarana, intruksi-intruksi dan penciptaan iklim yang diperlukan staf teknisi atau profesional yang terlibat dalam proses produksi (hasil).

Ditingkat bawah adalah fungsi pengawas dalam kontak langsung dengan pekerjapekerja profesional dan teknis, fungsi pengawasan sumber-sumber serta menjalin agar kegiatan-kegiatan profesional dan teknis dilaksanakan sesuai dengan standar yang telah ditetapkan. Efesiensi dan efektifitas penyelengaraan pemerintahan desa,pemerintah desa harus didukung dengan tata usaha yang benar.tata usaha adalah kegiatan mencatat semua proses penyelengaraan pemerintahan desa yang disebut administrasi desa.jadi, administrasi desa adalah keseluruhan proses kegiatan pencatatan data dan informasi mngenai penyelengaraan pemerintahan desa pada buku administrasi desa, administrasi desa sangat penting bagi kegiatan penyelengaraan pemerintahan desa. Pemerintahan desa akan berjalan dengan lancar manakala didukung oleh sistem tata usaha/administrasi yang benar, rapi, dan tertip. sistem administrasi yang benar, rapi dan tertip akan memberikan data dan informasi yang mudah dan sistematis yang sangat berfungsi untuk pengambilan keputusan, pembuatan rencana, kontrol kegiatan, dan komunikasi dan informasi baik kedalam maupun keluar organisasi.

Sedangkan pelayanan Publik menurut keputusan Menteri Negara Pendayagunaan Aparatur Negara (MENPAN) no. 81 tahun 1993 adalah segala bentuk kegiatan pelayanan umum yang dilaksnakan oleh instansi pemerintah pusat, daerah dan lingungan BUMN dearah dalam bentuk barang dan atau jasa, baik dalam rangka upaya pemenuhan kebutuhan perundang-undangan. Pelayanan adalah setiap kegiatan yang menguntungkan dalam suatu kumpulan atau kesatuan, dan menawarkan kepuasan meskipun hasilnya tidak terikat pada suatu produk secara fisik. Selanjutnya pelayanan yaitu suatu kegiatan atau urutan kegiatan yang terjadi dalam interaksi langsung antar seseorang denga orang lain atau media secara fisik dan menyediakan kepuasan pelanggan.

Pelayanan public adalah kegiatan atau rangkaian kegiatan dalam rangka pemenuhan kebutuhan dasar sesuai dengan hak-hak sipil setiap warga Negara dan penduduk atas suatu barang, jasa, dan atau pelayanan administrasi yang disediakan oleh penyelenggara pelayanan publik. Pemberian pelayanan public untuk keperluan organisasi atau masyrakat yang mempunyai kepentingan pada organisasi itu sesuai dengan aturan pokok dan tata cara yang ditetapkan. Dengan demikian pelayanan public pemenuhan keinginanan dan kebutuhan masyarakat oleh penyelenggara Negara. Pelayanan prima 
adalah pelayanan yang bermutu untuk meningkatkan keprimaan. Oleh karena itu, pelayanan umum yang prima, yaitu:

1. Meningkatkan mutu produktifitas pelaksanaan tugas dan fungsi instansi pemerintah dibidang pelayanan.

2. Mendorong upaya mengefektifitaskan sistem kerja dan fakta pelaksanapelayanan sehingga pelayanan dapat dilaksanakan secara lebih berdaya guna dan berhasil guna.

3. Mendorong tumbuhnya kreatifitas, prakarsa dan peran serta masyarakatdalam pembangunan serta meningkatkan kesejahteraan masyarakat.

Pelayanan adalah usaha melayani kebutuhan orang lain. Pelayanan pada dasarnya adalah kegiatan yang ditawarkan oleh organisasi perorangan kepada konsumen yang bersifat tidak terwujud dan tidak dapat dimiliki. Sehingga fungsi penertiban adminsitrasi desa sidomulyo terhadap pelayanan publik dimana pemerintah dalam meningkatkan kesejatraan sosial, pemerintah harus ikut turun tangan. Hal itu dilakukan untuk memberikan pelayanan masyarakat seperti pelayanan kesehatan, pelayanan untuk mengurus dokumen kependudukan seperti, KK, KTP, Akta kelahiran, Akta kematian, Akta Perkawinan, mana kala di perlukan untuk kepentingan sekolah, melamar pekerjaan, naik haji/umroh, keringanan biaya rumah sakit, kredit, perbangkan, daftar gaji pensiun, asuransi kematian, maupun kepentingan lainya.

Sungguh eronis dijaman globalisasi ini jika masih ada masyarakat yang menganggap bawasannya tidak pentinya suatu administrasi atau dokumen dokumen kependudukasn dalam kehidupan bernegara karena dalam kehidupan bernegara dokumen dokumen itu sangat di butuhkan tapi masyarakat kadang tidak menghiraukan itu seperti kelengkapan administrasi kependudukan diantara lain Akta kelahiran, Kartu Keluarga (KK), Kartu tanda penduduk (E-KTP) dan akta nikah. Seperti halnya di desa sidomulyo sebagaina masyarakat belum mengurus adminstrasi kependudukan sehinnga berdampak dimana pelayanan pablik yang di berikan oleh pemerintah terhambat seperti pelayanan pelayanan publik yang menggunakan administrasi kepemdudukan, sehinnga pemerintah desa perlu mensosialisasikan tentang pentingnya administrasi kependudukan terhadap tingkat pelayanan yang di berikan oleh pemerintahan desa.

\section{KESIMPULAN}

Penertiban administrasi bagi pemerintahan desa sangat penting karena Dari penjelasan di atas maka dapat di simpulkan adminstrasi adalah Kegiatan ini meliputi kegiatan perencanaan, pengorganisasian, pengerakan dan pengawasan. Pemerintahan desa harus dilaksanakan dengan baik sehingga mampu mendukung pelaksanaan fungsi administrasi pemerintahan di desa. Disamping itu pemerintahan desa dan kelurahan merupakan salah satu aspek yang dianggap penting dalam rangka peningkatan dan pengembangan kinerja aparatur pemerintahan desa serta pelaksanaan pembangunan di desa. Dengan demikian pelayanan publik pemenuhan keinginanan dan kebutuhan masyarakat oleh penyelenggara Negara. Pelayanan prima adalah pelayanan yang bermutu untuk meningkatkan keprimaan.

\section{DAFTAR RUJUKAN}

Arsjad, M. F. (2018). Peranan Aparat Desa dalam Pelaksanaan Administrasi Pemerintahan Desa di Desa Karyamukti Kecamatan Mootilango Kabupaten Gorontalo. Journal of Public Administration Studies, 1(1), 16-32. http://jurnal.unigo.ac.id/index.php/gjpads/article/download/176/171

Hidayat, E. S. (2018). Analisis Implementasi Kebijakan Administrasi Kependudukan Pada Dinas Kependudukan Dan Pencatatan Sipil Kabupaten Garut. Dinamika: Jurnal 
Ilmiah Ilmu Administrasi Negara, 5-16. https://doi.org/10.25157/dinamika.v5i4.1741

Nasikhah, M. A. (2019). Inovasi Pelayanan Transportasi Publik Berbasis Teknologi Informasi. Jurnal Inovasi Ilmu Sosial Dan Politik (JISoP), 1(1), 26-37. https://doi.org/10.33474/jisop.v1i1.2670

Paramitha, L. M., Domai, T., \& Suwondo. (2013). KINERJA APARAT PEMERINTAH DESA DALAM RANGKA OTONOMI DESA (Studi di Desa Gulun, Kecamatan Maospati, Kabupaten Magetan). Jurnal Adminitrasi Publik (JAP), 1(4), 91-100. http://administrasipublik.studentjournal.ub.ac.id/index.php/jap/article/view/119

Pratama, M. R. (2020). Trajektori Studi Administrasi Publik. Jurnal Inovasi Ilmu Sosial Dan Politik (JISoP), 2(2), 169-179. https://doi.org/10.33474/jisop.v2i2.6650

Pujiatna, T., Mascita, D. E., \& Gloriani, Y. (2019). Pembinaan tata bahasa indonesia pada administrasi surat-menyurat dan ruang publik. Jurnal Inovasi Hasil Pengabdian Masyarakat (JIPEMAS), 2(2), 170-178. https://doi.org/10.33474/jipemas.v2i2.2851

Saleh, H. A. (2008). Kajian tentang pemerintahan desa perspektif otonomi daerah. Government: Jurnal Ilmiah Ilmu Pemerintahan, 1(1), 1-23. https://journal.unhas.ac.id/index.php/government/article/view/1119

Suharto, D. G. (2012). Penyelenggaraan Pemerintahan Desa Dalam Perspektif Desentralisasi Administratif Dan Desentralisasi Politik. Jurnal Bina Praja, 4(3), 153160. https://doi.org/10.21787/jbp.04.2012.153-160 